\title{
SIGNIFICANCE OF DNA BASE COMPOSITION IN THE CLASSIFICATION OF YEAST GENUS PICHIA
}

\author{
TAKASHI NAKASE AND KAZUO KOMAGATA ${ }^{1}$ \\ Central Research Laboratories, Ajinomoto Co., Inc., Kawasaki, Japan
}

(Received June 25, 1970)

The DNA base composition (GC content) of 53 cultures of Pichia and supposed related yeasts, which represented 35 species and a variety, was investigated. The GC content of Pichia ranged from 28.3 to $50.2 \%$, and intrageneric variation was about $22 \%$. Any prominent subgroups could not be detected within the genus and this genus was supposed to be very heterogeneous from the taxonomic points of view.

Since the publication of the monograph of LODDER and KREGER-VAN RIJ (1), in which only four species were included in the genus Pichia, a number of new species have been described in this genus and related genera. As a result of amendment of the definition of Pichia by PHAFF (2) to admit many species previously assigned to the genera Petasospora, Saccharomyces, and Debaryomyces, the genus Pichia became a large and complex genus and systematic studies became necessary for clarification of interrelationships among the species. This attempt has been made by BOIDIN et al. (3), PONCET (4), and SPENCER and GORIN (5).

In a previous work (6), the present authors investigated the GC content of DNA of the genus Hansenula and found that several groups were discriminated on the basis of GC content and serological characteristics. The genus Pichia is often compared with the genus Hansenula because these two genera are differentiated only by one character, assimilation of nitrate as a sole nitrogen source. Therefore, the authors examined GC contents of the genus Pichia with the expectation that subgroups may be found within this genus.

\section{MATERIALS AND METHODS}

Microorganisms. Fifty-three cultures of Pichia and supposed related

1 Present address: The Institute of Applied Microbiology, University of Tokyo, Hongo, Tokyo, Japan. 
Table 1. DNA base composition of the genus Pichia

\begin{tabular}{|c|c|c|c|c|}
\hline Species & Strain & Source & $\underset{\left({ }^{\circ} \mathrm{C}\right)}{\mathrm{Tm}}$ & $\begin{array}{l}\mathrm{GC} \text { content } \\
(\text { mol. } \%)\end{array}$ \\
\hline P. rhodanensis & AJ 5074 & CBS 5518 & 89.9 & 50.2 \\
\hline P. guilliermondii & AJ 4498 & IFO 0961 & 87.6 & 44.6 \\
\hline "I & AJ 4499 & IFO 0566 & 87.5 & 44.4 \\
\hline P. pinus & AJ 5082 & CBS 744 & 87.5 & 44.4 \\
\hline P. wickerhamii & AJ 5086 & CBS 4107 & 87.0 & 43.2 \\
\hline P. ohmeri & AJ 5085 & CBS 5367 & 86.6 & 42.2 \\
\hline$\prime \prime$ & AJ 5088 & TUEA No. 230 & 86.7 & 42.4 \\
\hline P. membranaefaciens & AJ 4110 & IFO 0460 & 86.5 & 42.0 \\
\hline "l & AJ 4112 & RIFY WF-30 & 86.3 & 41.5 \\
\hline$\prime \prime$ & AJ 4113 & RIFY WF-80 & 86.7 & 42.4 \\
\hline "1 & AJ 4133 & soil & 86.5 & 42.0 \\
\hline$\prime \prime$ & AJ 4140 & soil & 86.5 & 42.0 \\
\hline "l & AJ 4141 & soil & 86.4 & 41.7 \\
\hline P. fermentans & AJ 4458 & $\begin{array}{l}\text { C. krusei var. transi- } \\
\text { toria }(\mathrm{H} . \text { Saëz) }\end{array}$ & 86.6 & 42.2 \\
\hline "l & AJ 4891 & convenience food & 86.6 & 42.2 \\
\hline P. pastoris & AJ 5076 & CBS 704 & 86.1 & 41.0 \\
\hline "I & AJ 5291 & J-3092 (IFO 1013) & 85.8 & 40.2 \\
\hline P. pijperi & AJ 5075 & CBS 2887 & 86.0 & 40.7 \\
\hline P. strassburgensis & AJ 5068 & CBS 2939 & 85.8 & 40.2 \\
\hline P. quercuum & AJ 5079 & CBS 2283 & 85.7 & 40.0 \\
\hline P. farinosa & AJ 4134 & IFO 0465 & 85.2 & 38.8 \\
\hline "I & AJ 4136 & corn & 85.5 & 39.5 \\
\hline 11 & AJ 4138 & P. minuscula NI 7646 & 85.6 & 39.8 \\
\hline F. bovis & AJ 5069 & CBS 2616 & 85.6 & 39.8 \\
\hline P. toletana & AJ 5084 & CBS 2504 & 85.4 & 39.3 \\
\hline P. haplophila & AJ 5078 & CBS 2028 & 85.3 & 39.0 \\
\hline P. etchellsii & AJ 5083 & CBS 2011 & 85.1 & 38.5 \\
\hline P. kudriavzevii & AJ 4146 & CBS 5147 & 85.1 & 38.5 \\
\hline P. salictaria & AJ 5080 & CBS 5456 & 84.8 & 37.8 \\
\hline P. zaruensis & AJ 4142 & exudate of tree (11) & 84.2 & 36.3 \\
\hline II & AJ 4143 & soil $(11)$ & 84.5 & 37.1 \\
\hline P. vini & AJ 4266 & IFO 0795 & 84.4 & 36.8 \\
\hline P. vini var. melibiosi & AJ 5077 & CBS 5254 & 84.6 & 37.3 \\
\hline P. terricola & AJ 4137 & IFO 0933 & 84.3 & 36.6 \\
\hline "l & AJ 5368 & J-9049 (IFO 0933) & 84.4 & 36.8 \\
\hline P. trehalophila & AJ 5070 & CBS 5361 & 83.5 & 34.6 \\
\hline P. polymorpha & AJ 4148 & moss & 82.9 & 33.2 \\
\hline
\end{tabular}


Table 1. (Continued)

\begin{tabular}{|c|c|c|c|c|}
\hline Species & Strain & Source & $\underset{\left({ }^{\circ} \mathrm{C}\right)}{\mathrm{Tm}}$ & $\begin{array}{c}\mathrm{GC} \text { content } \\
(\mathrm{mol} . \%)\end{array}$ \\
\hline P. saitoi & AJ 4144 & (K. Kodama) & 82.5 & 32.2 \\
\hline P. fluxuиm & AJ 5072 & CBS 2237 & 82.5 & 32.2 \\
\hline P. chambardii & AJ 4283 & IFO 1029 & 81.7 & 30.2 \\
\hline P. kluyveri & AJ 4145 & ATCC 9768 & 80.9 & 28.3 \\
\hline$\prime \prime$ & AJ 4426 & banana & 81.0 & 28.5 \\
\hline D. vanriji & AJ 5058 & CBS 3024 & 82.6 & 32.4 \\
\hline E. fibuligera & AJ 4270 & IAM 4247 & 85.4 & 39.3 \\
\hline E. fasciculata & AJ 5061 & CBS 5514 & 84.9 & 38.0 \\
\hline C. zeylanoides & AJ 4679 & ATCC 7351 & 91.8 & 54.9 \\
\hline 11 & AJ 4741 & frozen food, $\mathrm{p}-16(27)$ & 91.7 & 54.7 \\
\hline C. mycoderma & AJ 4413 & RIFY WF-64 & 86.7 & 42.2 \\
\hline C. krusei & AJ 4421 & IFO 0011 & 85.2 & 38.8 \\
\hline "I & AJ 4457 & ATCC 6258 & 85.4 & 39.3 \\
\hline II & AJ 4773 & C. tamarindii $\mathrm{CBS} 2457$ & 85.3 & 39.0 \\
\hline C. natalensis & AJ 4772 & $\begin{array}{l}\text { 29-44-1 (A. Kocková- } \\
\text { Kratochvílová) }\end{array}$ & 84.4 & 36.8 \\
\hline$T$. inconspicua & AJ 5138 & IFO 0621 & 83.9 & 35.6 \\
\hline
\end{tabular}

yeasts which represented thirty-five species and one variety were employed. Sources of cultures are shown in Table 1.

Cultivation and harvest of yeasts, and isolation of DNA. Cultivation and harvest of yeasts, and isolation of DNA essentially followed the procedures previously reported (7). For the purpose of digestion of RNA, deproteinized DNA solution was incubated with ribonuclease as described (7). However, an overnight incubation is usually sufficient and this was different from the case of previous work.

Determination of DNA base composition. The DNA base composition was calculated from the thermal denaturation temperature (Tm) of DNA according to the procedure of MARMUR and DOTY $(8)$. Tm was measured by the apparatus described by YAMADA and KomagATA (9).

\section{RESULTS AND DISCUSSION}

DNA base composition (GC content) of the strains of the genus Pichia and related genera calculated from the Tm is shown in Table 1. All the preparations employed for Tm determination gave monophasic melting curves and were considered to be free from mitochondrial DNA.

In the previous paper (7), the present authors reported the GC contents of DNA from three species of Pichia; P. membranaefaciens (40.5\%), P. vini 


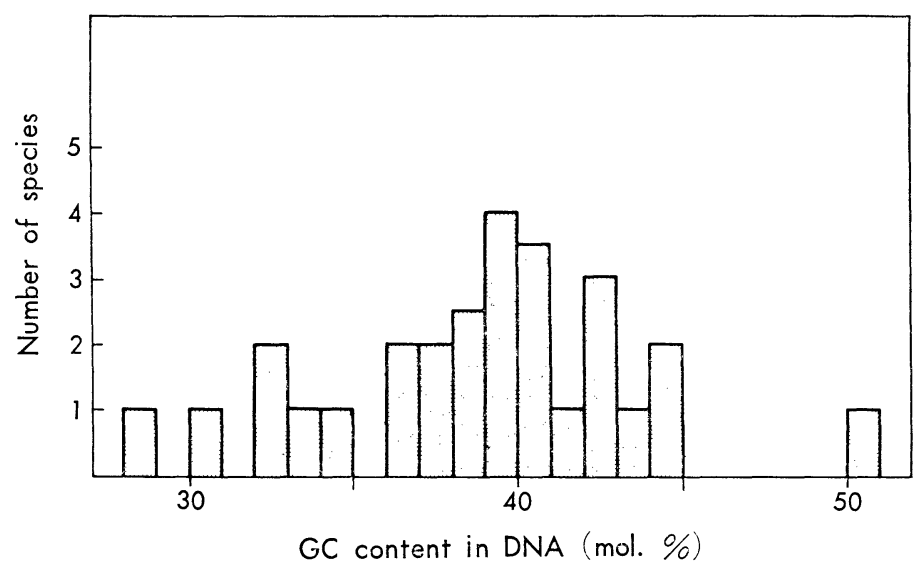

Fig. 1. Distribution of GC content in DNA from the genus Pichia.

$\left(34.5^{c} c\right)$, and $P$. kluyveri $(26-27 \%)$. Tm values obtained in the present experiment were somewhat higher than those previously reported as a result of using an improved apparatus for Tm determination described by YAMADA and Komagata (9). Namely, $41.5-42.4 \%, 36.8 \%$, and $28.3-28.5 \%$ of GC contents were obtained respectively for $P$. membranaefaciens, $P$. vini, and $P$. kluyveri (Table 1).

The GC contents of DNA of the members of Pichia ranged from 28.3 to $50.2 \%$, and any prominent groups of the species were not found (Fig. 1). This range of intrageneric variation (about 22\%) was the largest among ascosporogenous genera of yeasts hitherto investigated $(6,7,10)$. This is quite natural since the genus Pichia is considered to be not clearly defined, and often difficult to be distinguished from other genera of sporogenous yeasts, especially Debaryomyces, Endomycopsis and Saccharomyces. The genus Pichia is often compared with the genus Hansenula since both genera are separated only by one character, assimilation of nitrate as a sole nitrogen source. It is noteworthy that prominent groups of the species with similar GC contents and similar taxonomic criteria cannot be found in the genus Pichia. This contrasts with the case of the genus Hansenula in which such groups were found $(6)$. Of the saturn-shaped spored pichias, $P$. saitoi and $P$. zaruensis were studied. It is interesting that these two species differ about $5 \%$ in the GC content in spite of a close similarity in taxonomic criteria commonly employed (11). In the case of Hansenula, saturn-shaped spored species exhibited similar values in GC contents and were considered to make a natural group (6). According to KodAma (12), spore forms of Pichia are classified into five groups, while those of Hansenula are divided into only two groups. The genus Pichia is supposed to be a very complex genus and may consist of many kinds of yeasts with different phylogenetic origin.

BOIDIN et al. (3) classified the members of true Pichia (with hat- or 
Table 2. DNA base composition of Pichia and the classification by BOIDIN et al. (3).

\begin{tabular}{|c|c|c|c|}
\hline \multicolumn{2}{|c|}{ Group } & Species & $\begin{array}{c}\mathrm{GC} \text { content } \\
\left(\mathrm{mol} . \mathrm{o}_{0}\right)\end{array}$ \\
\hline \multirow{2}{*}{$\begin{array}{l}\text { Guilliermondii- } \\
\text { fibuligera }\end{array}$} & Guilliermondii & $\begin{array}{l}P . \text { guilliermondii } \\
P . \text { scolyit } \\
P . \text { burtonii } \\
P . \text { ohmeri }\end{array}$ & $\begin{array}{l}44.4-44.6 \\
\text { NT } \\
\text { NT } \\
42.2-42.4\end{array}$ \\
\hline & Fibuligera & $\begin{array}{l}\text { P. strassburgensis } \\
P . \text { fbuligera } \\
\text { P. monospora } \\
\text { P. rhodanensis } \\
\quad \text { (P. bovis }) \\
\quad \text { (P. xylosa) } \\
\quad \text { (P. wickerhamii) } \\
\quad \text { (P. toletana }) \\
\text { P. fasciculata } \\
\text { P. media }\end{array}$ & $\begin{array}{l}40.2 \\
39.3 \\
\text { NT } \\
50.2 \\
39.8 \\
\text { NT } \\
43.2 \\
39.3 \\
38.0 \\
\text { NT }\end{array}$ \\
\hline \multicolumn{2}{|c|}{ Pijperi-pini } & $\begin{array}{l}P . \text { pijperi } \\
P . \text { salictaria } \\
P . \text { chambardii } \\
P . \text { pastoris } \\
P . \text { trehalophila } \\
P . \text { pini }\end{array}$ & $\begin{array}{l}40.7 \\
37.8 \\
30.2 \\
40.2-41.0 \\
34.6 \\
44.4\end{array}$ \\
\hline \multicolumn{2}{|c|}{ Membranaefaciens } & $\begin{array}{l}\text { P. haplophila } \\
\text { P. saitoi } \\
\text { P. fermentans } \\
\quad \text { (P. kluyveri) } \\
\text { P. membranaefaciens } \\
\quad \text { (P. saccharophila) } \\
\quad \text { P. silvestris) } \\
\text { P. delftensis } \\
\text { P. farinosa } \\
\quad \text { (P. sake) } \\
\quad \text { (P. miso) } \\
\text { (P. minuscula) }\end{array}$ & $\begin{array}{l}39.0 \\
32.2 \\
42.2 \\
28.3-28.5 \\
41.5-42.4 \\
\text { NT } \\
\text { NT } \\
\text { NT } \\
38.8-39.8 \\
\text { NT } \\
\text { NT } \\
39.8\end{array}$ \\
\hline
\end{tabular}


Table 2. (Continued)

\begin{tabular}{c|c|c}
\hline Group & Species & $\begin{array}{c}\text { GC content } \\
(\mathrm{mol} \%)\end{array}$ \\
\hline Polymorpha & $P$. polymorpha & 33.2 \\
& $P$. pseudopolymorpha & $\mathrm{NT}$ \\
& $P$. robertsii & $\mathrm{NT}$ \\
& $P$. vini & 36.8 \\
& $(P$. carsonii) & $\mathrm{NT}$ \\
& $(P$. faecalis $)$ & $\mathrm{NT}$ \\
& $(P$. etchellsii) & 38.5 \\
& $(P$. vini var. & 37.3
\end{tabular}

NT: not tested

saturn-shaped ascospores) into three groups, "guilliermondii-fibuligera," "pijperi-pini," and "membranaefaciens." They excluded round spored species ("polymorpha" group) from the genus Pichia and stated that taxonomic position of these species must be debated. As shown in Table 2, the members of "guilliermondii-fibuligera" group exhibited the GC content of 38.0-50.2\%. Of the species of subgroup "guilliermondii," two species employed in the present experiment ( $P$. guilliermondii and $P$. ohmeri) exhibited similar GC contents, $44.4-44.6 \%$ and $42.2-42.4 \%$, respectively, while an intragroup variation of GC contents in subgroup "fibuligera" reached about $12 \%$ and suggests the heterogeneity of the subgroup. Of the members of this group, $P$. rhodanensis, $P$. xylosa, P. toletana, $P$. bovis, and $P$. wickerhamii show minor differences in taxonomic criteria commonly employed so that diverse synonyms have been proposed, namely, $P$. xylosa with $P$. rhodanensis $(13,14), P$. xylosa with $P$. toletana (15), and P. xylosa, P. bovis, P. toletana, and P. wickerhamii with $P$. rhodanensis $(3,16)$. Although the authors did not study $P$. xylosa, other yeasts exhibited three different GC contents, $50.2 \%$ for P. rhodanensis, $43.2 \%$ for $P$. wickerhamii, and 39.3-39.8\% for $P$. toletana and $P$. bovis, so that they are assumed to represent at least three different species. PONCET (4) reported, on the basis of factor analysis, that $P$. bovis, $P$. rhodanensis, $P$. $x y l o s a$, and $P$. wickerhamii should be retained as separate species. It is noteworthy that $P$. rhodanensis exhibited the GC values extremely higher than those of the other species mentioned above in spite of a resemblance in taxonomic criteria commonly employed.

Intragroup variation in GC contents in "pijperi-pini" group was found to be about $14 \%$, and this group is also assumed to consist of heterogeneous members. BoIDIN et al. (17) reported that P. trehalophila occupied an intermediate position between $P$. pastoris and $P$. pini ( $P$. pinus), and PHAFF et al. (18) also pointed out a resemblance of $P$. trehalophila to $P$. pinus. However, 
P. trehalophila is considered not so closely related to $P$. pastoris and $P$. pinus since the former exhibited the GC values $6-10 \%$ higher than those of the latter two species. The variation in the GC contents found in "membranaefaciens" group was about 14\% (Table 2), and denotes the heterogeneity of the group. It is interesting that $P$. fermentans and $P$. kluyveri showed quite different GC contents, $42.2 \%$ and $28.3-28.5 \%$, respectively, in spite of a close resemblance in taxonomic criteria commonly employed. Since the description of P. kluyveri by BEDFORD (19), a considerable amount of discussions has been made on the validity of this species. LODDER and KREGER-VAN RIJ (1) regarded this species as a synonym of $P$. fermentans, while DE CARMAGO and PHAFF (20) reported that $P$. kluyveri differs from $P$. fermentans in the assimilation of D-xylose and the formation of pseudomycelia. KREGER-VAN RIJ (15) accepted De Carmago and Phaff's opinion though she found that $P$. kluyveri can form primitive pseudomycelia. However, PIGNAL and BoIDIN (21) found that $P$. kluyveri could assimilate $\mathrm{D}$-xylose, and again they regarded this species as a synonym of $P$. fermentans. It is apparent that $P$. kluyveri is a quite different species from $P$. fermentans because their GC contents are extremely different. Practically, these species can be discriminated by assimilation of D-xylose and requirement of biotin and pyridoxine. Namely, $P$. fermentans rapidly assimilates $\mathrm{D}$-xylose and requires neither biotin nor pyridoxine, while $P$. kluyveri assimilates $\mathrm{D}$-xylose latently and very weakly or not in some strains, and requires both biotin and pyridoxine. $P$. minuscula, which was considered as a synonym of $P$. farinosa $(15,21)$, showed a GC value similar to that of $P$. farinosa (Table 2).

The members of "polymorpha" group, which were excluded from the genus Pichia by BoIDIN et al. (3), showed GC contents with a relatively small intragroup variation though the number of species employed was rather small. By the facts enumerated above, classification of Pichia by BoIDIN et al. (3) is considered not to reflect the natural relationship among species, though it gives many suggestions for the classification of the genus Pichia.

SPENCER and GORIN (5) classified the members of Pichia into five groups on the basis of similarities in the proton magnetic resonance (PMR) spectra of mannans isolated from these yeasts. The relation of their grouping to the GC content is shown in Table 3 . Intragroup variation in GC contents is about $22 \%$ in group I, $16 \%$ in group II, $11 \%$ in group III, $2 \%$ in group IV, and $7 \%$ in group V. Of the most heterogeneous group I, Candida zeylanoides showed GC values 10 to $22 \%$ higher than those of other members of this group. When this species is omitted, intragroup variation of this group is reduced to about $12 \%$ in the GC content though this value of variation is yet rather wide to regard that the members of this group make a natural group. Of the three subgroups within this group, group Ic is the most heterogeneous (Table 3). In spite of a great difference in the GC contents of DNA, SPENCER and GORIN (5) reported that $C$. zeylanoides forms a mannan whose PMR spectrum shows all the signals present in that of $C$. guilliermondii. It is apparent that PMR 
Table 3. Grouping of Pichia based on PMR spectra of mannans (5) and DNA base composition

\begin{tabular}{|c|c|c|c|}
\hline \multicolumn{2}{|c|}{ Group } & Species & $\begin{array}{c}\mathrm{GC} \text { content } \\
(\mathrm{mol} \%)\end{array}$ \\
\hline \multirow{3}{*}{ I } & Ia & $\begin{array}{l}P . \text { farinosa } \\
P . \text { pseudopolymorpha } \\
P . \text { polymorpha } \\
P . \text { quercuum }\end{array}$ & $\begin{array}{l}38.8-39.8 \\
\text { NT } \\
33.2 \\
40.0\end{array}$ \\
\hline & $\mathrm{Ib}$ & $\begin{array}{l}P . \text { etchellsii } \\
P . \text { vini } \\
P . \text { haplophila }\end{array}$ & $\begin{array}{l}38.5 \\
36.8 \\
39.0\end{array}$ \\
\hline & Ic & $\begin{array}{l}P . \text { vanriji } \\
P . \text { robertsii } \\
P . \text { guilliermondii } \\
P . \text { zeylanoides }\end{array}$ & $\begin{array}{l}32.4 \\
\text { NT } \\
44.4-44.6 \\
54.7-54.9\end{array}$ \\
\hline \multirow{3}{*}{ II } & IIa & $\begin{array}{l}\text { C. krusei } \\
P . \text { fluxuum } \\
\text { P. kluyveri } \\
\text { P. angophorae } \\
\text { P. pinus } \\
\text { P. trehalophila }\end{array}$ & $\begin{array}{l}38.8-39.3 \\
32.2 \\
28.3-28.5 \\
\text { NT } \\
44.4 \\
34.6\end{array}$ \\
\hline & IIb & $\begin{array}{l}\text { P. membranaefaciens } \\
\text { C. mycoderma } \\
\text { P. terricola }\end{array}$ & $\begin{array}{l}41.5-42.4 \\
42.2 \\
36.6-36.8\end{array}$ \\
\hline & IIc & $\begin{array}{l}P . \text { fermentans } \\
P . \text { orientalis }\end{array}$ & $\begin{array}{l}42.2 \\
38.5\end{array}$ \\
\hline \multirow{3}{*}{ III } & IIIa & $\begin{array}{l}P . \text { rhodanensis } \\
P . \text { ohmeri }\end{array}$ & $\begin{array}{l}50.2 \\
42.2-42.4\end{array}$ \\
\hline & IIIb & $\begin{array}{l}\text { P. pijperi } \\
\text { C. tepae }\end{array}$ & $\begin{array}{l}40.7 \\
\text { NT }\end{array}$ \\
\hline & IIIC & $\begin{array}{l}P . \text { pastoris } \\
P . \text { toletana }\end{array}$ & $\begin{array}{l}40.2-41.0 \\
39.3\end{array}$ \\
\hline IV & & $\begin{array}{l}P . \text { strassburgensis } \\
P . \text { salictaria } \\
P . \text { bovis }\end{array}$ & $\begin{array}{l}40.2 \\
37.8 \\
39.8\end{array}$ \\
\hline V & & $\begin{array}{l}\text { P. chambardii } \\
\text { C. natalensis }\end{array}$ & $\begin{array}{l}30.2 \\
36.8\end{array}$ \\
\hline
\end{tabular}

NT: not tested 
spectra of mannans represent a resemblance only of a part of the structure of cell wall and not a resemblance of microorganism as a whole. Subgroups Ia and Ic exhibited relatively small, or small intragroup variations. Of the group II, group IIa is considered the most heterogeneous subgroup exhibiting about $16 \%$ of intragroup variation in the GC content. Of the species of group IIb, $P$. membranaefaciens and its imperfect form $C$. mycoderma showed similar GC values, while $P$. terricola exhibited a value about $6 \%$ lower than those of the former two species. SPENCER and GorIN (5) pointed out that the PMR spectra of this subgroup resembled those of $H$. angusta and $H$. minuta. It is noteworthy that a considerable number of common antigens were found by TsuchiY et al. (22) among the species of group IIb and H. angusta and H. minuta. These species are considered to be closely related in the structure of cell walls but not necessarily in the level of DNA. A small variation was found in group IIc. SPENCER and GORIN (5) stated that Torulopsis inconspicua which they described as the imperfect form of P. fermentans is also included in this subgroup. However, this species showed a GC value $(35.6 \%)$ lower than those of the other species and is not considered to be the imperfect form of $P$. fermentans. It is interesting that $P$. orientalis and $C$. kruse $i$ are placed in separate subgroups, groups IIc and IIa, respectively, because $P$. orientalis (P. kudriavzevii) is regarded as the perfect form of $C$. krusei $(3,15)$. Further investigation is required to clarify this relationship in spite of a resemblance of GC contents between the two species. Variation found in subgroups in group III was not so large; about $8 \%$ in group IIIa and $1-2 \%$ in IIIc. As to group IIIb, only one species was studied. Species of group IV exhibited similar GC contents in spite of their large difference in carbon assimilation (15). SPENCER and GORIN (5) pointed out a resemblance of PMR spectra of mannans of this group to those obtained from group I of Hansenula. However, hansenulas of group I of SPENCER and GORIN have GC contents with wide variation, $12 \%(6)$. The last group showed a relatively small intragroup variation. As being discussed above, classification of Pichia by PMR spectra of mannans is inconsistent in many points with the data of GC contents. Of course, PMR spectrum of mannans is an important criterion for elucidating the phylogenetic relationship among yeasts because it represents a fine structure of mannans of the cell wall, but classification based only on this character is not considered to represent natural relationships among the yeasts.

PONCET (4) classified true Pichia into three groups on the basis of factor analysis. As shown in Fig. 2, each group showed a large intragroup variation of the GC content. This analysis seems to be only a reflection of phenotypical characteristics concerning fermentation and assimilation of carbon compounds.

In the case of Hansenula, GC contents and antigenic structures were consistent in many points $(6)$. Since only a restricted number of Pichia has been serologically studied, precise comparison cannot be made. However, it seems that some discrepancies may be present as shown in Table 4. It is apparent that the genus Pichia is a very complex genus and extensive studies 


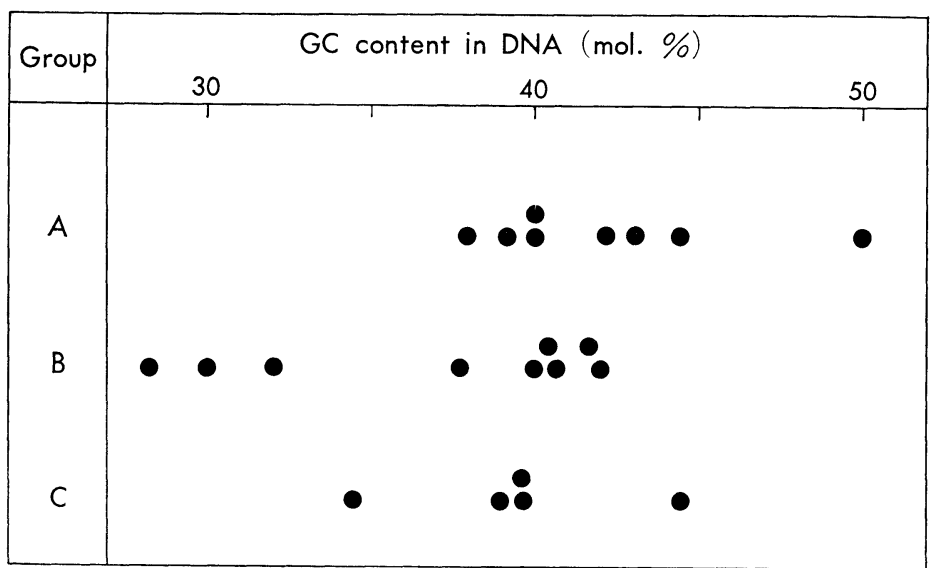

Fig. 2. Distribution of GC content in DNA in the groups of Pichia by PONCET (4) based on factor analysis.

- Mean value of the GC content of DNA in species.

Table 4. DNA base composition of species in Pichia group (genus) by TSUCHIYA et al. $(22,24)$

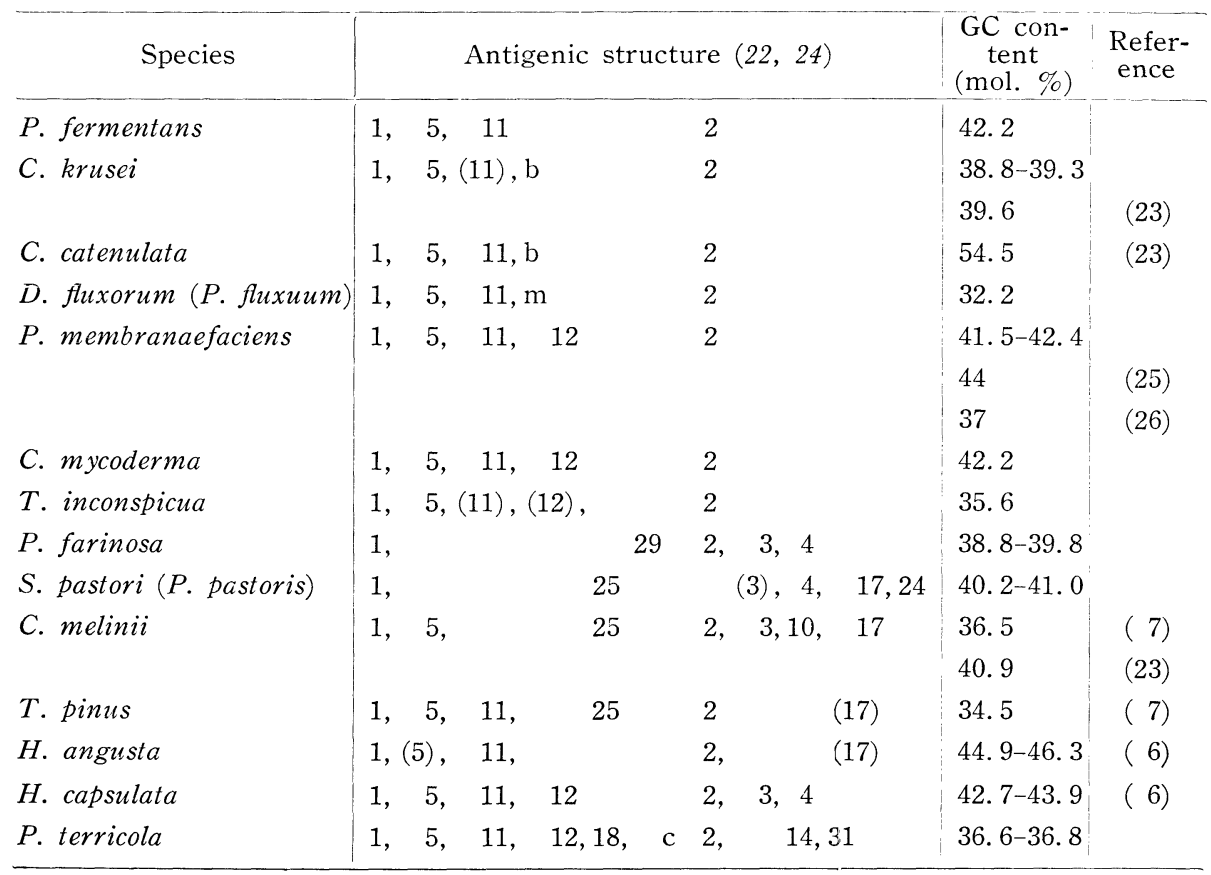


would be required to clarify the natural relationship among the species now included in this ambiguous genus.

The authors wish to thank Drs. S. Goto, T. Hasegawa, K. Kodama, A. KockováKratochvílová, M. Soneda, H. Saëz, and T. Tsuchiya for their kindness in sending the stock cultures. Many thanks are also due to Miss S. Miyazawa for her technical assistance.

\section{REFERENCES}

1) J. Lodder and N.J.W. Kreger-VAN RiJ, The Yeasts, a Taxonomic Study, North Holland Publ. Co., Amsterdam (1952).

2) H.J. Phaff, Antonie van Leeuwenhoek J. Microbiol. Serol., 22, 117 (1956).

3) J. Boidin, M.C. Pignal and M. Besson, Bull. Soc. Mycol. France, 81, 566 (1965).

4) S. Poncet, Antonie van Leeuwenhoek J. Microbiol. Serol., 33, 345 (1967).

5) J.F.T. Spencer and P.A.J. Gorin, Can. J. Microbiol., 15, 375 (1969).

6) T. Nakase and K. Komagata, J. Gen. Appl. Microbiol., 15, 85 (1969).

7) T. Nakase and K. Komagata, J. Gen. Appl. Microbiol., 14, 345 (1968).

8) J. Marmur and P. Doty, J. Mol. Biol., 5, 109 (1962).

9) K. Yamada and K. Komagata, J. Gen. Appl. Microbiol., 16, 215 (1970).

10) T. Nakase and K. Komagata, J. Gen. Appl. Microbiol., 16, 241 (1970).

11) T. Nakase and K. Komagata, J. Gen. Appl. Microbiol., 12, 347 (1966).

12) K. Kodama, Proceedings of the 2nd Symposium on Yeasts, Bratislava, 45 (1966),

13) N. van Uden and L. Do Carmo Sousa, J. Gen. Microbiol., 16, 385 (1957).

14) M. Miller, H.J. Phaff and H.E. Snyder, Mycopathol. Mycol. Appl., 16, 1 (1962).

15) N.J.W. Kreger-Van RiJ, A Taxonomic Study of the Yeast Genera Endomycopsis, Pichia, and Debaryomyces. Thesis, Leiden University (1964).

16) J. Boidin, M.C. Pignal, Y. Lehodey, A. Vey and F. Abadie, Bull. Soc. Mycol. France, 80, 396 (1964).

17) J. Boidin, F. Abadie and Y. Lehodey, Bull. Soc. Mycol. France, 81, 5 (1965).

18) H.J. Phaff, M.W. Miller and J.F.T. Spencer, Antonie van Leeuwenhoek J. Microbiol. Serol., 30, 132 (1964).

19) C.L. BEDFord, Mycologia, 34, 628 (1942).

20) R. De Carmago and H.J. Phaff, Food Res., 22, 367 (1957).

21) M.C. Pignal and J. Boidin, Bull. Soc. Mycol. France, 81, 197 (1965).

22) T. Tsuchiya, Y. Fukazawa and S. Kawakita, Mycopathol. Mycol. Appl., 26, 1 (1965).

23) A. Stenderup and A.L. BAK, J. Gen. Microbiol., 52, 231 (1968).

24) T. Tsuchiy A, Shinkin-to Shinkinsho, 10, 179 (1969).

25) R. STorck, J. Bacteriol., 91, 227 (1966).

26) K. Ouchi, H. Saito and Y. Ikeda, Agr. Biol. Chem. (Tokyo), 34, 95 (1970.

27) K. Komagata and T. NAKAse, Shokuhin Eiseigaku Zasshi, 8, 58 (1967). 